March 4, 2011

Grant Writing Workshop

Bethesda Marriott

Bethesda, Maryland

May 5-6, 2011

Mitral Conclave

Sheraton New York Hotel and Towers

New York, New York

May 26, 2011

AATS/ASCVTS Postgraduate Course*

Hilton Phuket Arcadia Resort \& Spa

Phuket, Thailand

*Co-sponsored by AATS.

**Content provided by AATS.

***Jointly sponsored by AATS.

\section{Heart Valve Summit: Medical, Surgical, and Interventional Decision Making}

October 7-9, 2010

Chicago Marriott Downtown Magnificent Mile

Chicago, Illinois, USA

The American College of Cardiology Foundation (ACCF) and the American Association for Thoracic Surgery (AATS) have once again joined together to develop a unified program, the 2010 Heart Valve Summit, that will provide a stimulating and in-depth look at valvular heart disease from both a cardiology and surgical point-of-view.

Using an integrative approach to managing medical, surgical, and interventional challenges in valvular heart disease, world-renowned cardiologists and cardiac surgeons will provide clinically relevant data on the current and future directions in valvular heart disease. Geared toward practicing clinicians across multiple disciplines, this unique program will include real-world interactive case-based patient management discussions, review of current practice guidelines, and focused breakout sessions.

\section{Program Directors:}

David H. Adams, MD, FACC

Steven F. Bolling, MD, FACC

Robert O. Bonow, MD, MACC

Howard C. Herrmann, MD, FACC, FSCAI
Honored Lectures:

Denton Cooley, MD

Valentin Fuster, MD, FACC

2009 Testimonials

"Excellent meeting. I always come back intellectually challenged and picking up new tricks, tips and pointers."

"This was one of the best meetings I have attended in my entire career. Putting surgeons together with cardiologists to discuss controversial topics is a superb format."

\section{REGISTRATION}

Space is limited, register today at www.acc.org/HVS2010

Please note that, if you are a member of $A A T S, \underline{A S E}, \underline{S C A I}$ or $\underline{S T S}$, you must submit your registration form through fax or mail to receive the member rate.

\section{ACCREDITATION}

\section{Physicians}

The American College of Cardiology is accredited by the Accreditation Council for Continuing Medical Education to provide continuing medical education for physicians.

The ACCF designates this educational activity for a maximum of 18.25 AMA PRA Category 1 Credits $^{\mathrm{TM}}$. Physicians should only claim credits commensurate with the extent of their participation in the activity.

\section{Nurses}

The American College of Cardiology Foundation is accredited as a provider of continuing nursing education by the American Nurses Credentialing Center's Commission on Accreditation.

The ACCF designates this educational activity for a maximum of 18.25 continuing education hours. Requirements for successful completion are attendance in a session in its entirety and completing the evaluation tool. Each attendee should only claim credits commensurate with the extent of their participation in the activity.

While offering credits noted above, the program is not intended to provide extensive training or certification in the field.

\section{The Western Thoracic Surgical Association}

\section{Applications for Membership}

Applications for membership in the Association must be received by the Membership Committee Chair no later than
March 1, 2011, to be considered at the 2011 Annual Meeting. Applicants must be sponsored by three members of the Association who are not members of the Membership Committee. Application forms will be issued only to sponsoring members.

Address correspondence to:

Chair, Membership Committee 
The Western Thoracic Surgical Association 900 Cummings Center

Suite 221-U

Beverly, MA 01915

978-927-8330; fax: 978-524-8890

wtsa@prri.com

\section{WTSA 37th Annual Meeting}

\author{
Save the Date!
}

June 22-25, 2011

The Broadmoor Hotel

Colorado Springs, Colorado

\section{The American Board of Thoracic Surgery}

\section{Notices}

The part I (written) examination was held on December 3. It is planned that this examination will be given at multiple sites throughout the United States using an electronic format. The closing date for registration is August 1 each year. Those wishing to be considered for examination must apply online at www.abts.org.

To be admissible for the Part II (oral) examination, a candidate must have successfully completed the Part I (written) examination.

A candidate applying for admission to the certifying examination must fulfill all the requirements of the Board in force at the time the application is received. Please address all communications to the American Board of Thoracic Surgery, 633 North St Clair Street, Suite 2320, Chicago, IL 60611 (telephone: 312-202-5900).

\section{Requirements for Maintenance of Certification}

Diplomates of the American Board of Thoracic Surgery (ABTS) who plan to participate in the Maintenance of Certification (MOC) process must hold an unrestricted medical license in the locale of their practice and privileges in a hospital accredited by the JCAHO (or other organization recognized by the ABTS). In addition, a valid ABTS certificate is an absolute requirement for entrance into the Maintenance of Certification process. If your certificate has expired, the only pathway for renewal of a certificate is to take and pass the Part I (written) and the Part II (oral) certifying examinations. The names of individuals who have not maintained their certificate will no longer be published in the American Board of Medical Specialties Directories. Diplomates' names will be published upon successful completion of the Maintenance of Certification process.

The CME requirements are 30 Category I credits earned during each year prior to application. At least half of these
CME hours need to be in the broad area of thoracic surgery. Category II credits are not allowed. Interested individuals should refer to the Booklet of Information for Maintenance of Certification for a complete description of acceptable CME credits. Diplomates will be expected to submit verification of CME earned.

Diplomates in the Maintenance of Certification process will need to provide a summary of their major cases performed during the year prior to application. The practice review should not exceed 100 cases.

Diplomates in the Maintenance of Certification process will be required to complete all sections of the SESATS self-assessment examination. It is not necessary for Diplomates to purchase SESATS individually, because it will be sent to them after their application has been approved.

Diplomates may apply for Maintenance of Certification in the year their certificate expires, or if they wish to do so, they may apply up to two years before it expires. However, the new certificate will be dated 10 years from the date of expiration of their original certificate or most recent recertification certificate. In other words, going through the Maintenance of Certification process early does not alter the 10-year validation. Diplomates certified prior to 1976 (the year that time-limited certificates were initiated) are also required to participate in MOC if they wish to maintain valid certificates.

The deadline for submission of application for the Maintenance of Certification is May 10 of each year. All ABTS diplomates will receive a letter from the Board outlining their individual timeline and MOC requirements. A brochure outlining the rules and requirements for Maintenance of Certification in thoracic surgery is available upon request from the American Board of Thoracic Surgery, 633 North St. Clair Street, Suite 2320, Chicago, IL 60611; telephone (312) 202-5900; fax (312) 202-5960; email info@abts.org. This booklet is also published on the website: www.abts.org. 